\title{
HEGEMONI KEKUASAAN TERHADAP SENI PEDALANGAN
}

Sutiyono

Faklutas Bahasa dan Seni Universitas Negeri Yogyakarta

Abstract

Tulisan ini akan menguraikan pokok bahasan relasi antara kekuasaan dan kesenian. Permahaman ini menyangkut bentuk afiliasi antara dalang wayang kulit (seniman) dengan pihak penguasa dalam hal ini adalah pemerintah atau negara (state). Aspek sub-bidang kajian ini adalah pertunjukan wayang kulit Jawa yang cukup mengental dengan kehidupan budaya masyarakat Jawa.

Kajian hegemoni kekuasaan terhadap seni pedalangan akan terarah jika harus melihat secara lurus pada tawaran Gramsci yang menyebutkan bahwa hegemoni memberikan definisi terhadap konsep politik dan konsekwensi pada tugas yang harus diemban oleh partai politik. Dalam hal ini partai politik harus mampu mengelola instrumen hegemoni untuk partai politik harus mampu mengelola instrumen hegemoni untuk
mengelabuhi masyarakat luas agar menjadi patuh dan mau dikuasai oleh partai mengelabuhi masyarakat luas agar menjadi patuh dan mau dikuasai oleh partai
politik tersebut. Seperti langkah-langkah yang diambil oleh partai Golkar politik tersebut. Seperti langkah-langkah yang diambil oleh partai Golkar
sebagai kendaraan politik rezim penguasa Orde Baru yakni dengan mengelola pertunjukan wayang sebagai wadah ekspresi sosial dan interaksi antara penguasa dan rakyat. Sebelum wadah ini efektif dan memadai, maka instrumen yang seni pedalangan harus dihegemoni terlebih dahulu. Bentuk kesenian beserta dalang dan komunitasnya harus ditaklukkan, agar semua pesan dan doktrin penguasa terhadap kesenian dapat tercapai. Kesenian benarbenar dapat menjadi kuda emas, yakni kendaraan politik yang manis dan jitu untuk memperoleh dan mempertahankan kekuasaan.

Kata kunci: wayang, seni pedalangan, dan hegemoni

\section{PENDAHULUAN}

Pengerahan massa dalam jumlah sangat besar pada pemilihan umum di bawah rezim Orde Baru (1966-19998) dalam konteks legitimasi kekuasaannya merupakan sesuatu yang sangat menarik untuk dikaji. Hal ini disebabkan salah satu keunggulan rezim Orde Baru bila dibandingkan dengan rezim yang lain dalam pelaksanaan mekanisme perpolitikan di Indonesia adalah terletak pada kesinambungan pelaksanaan pemilihan umum (pemilu) yang dimulai tahun 1971, 1977, 1982, 1987, 1992, dan 1997 (Kristiadi, 1994). Konsistensi terhadap mekanisme perpolitikan itu telah menjadi sebuah sistem perpolitikan dan pemerintahan yang dianggap stabil dibawah komando kekuasaan rezim Orde Baru, sekaligus sebuah fenomena kekuasaan yang terlama di Indonesia.

Tidak dapat dipungkuri, bahwa dalam memperoleh dukungan massa yang sebanyak-banyaknya, rezim Orde Baru sebagai penyelenggara kekuasaan memanfaatkan Partai Golkar sebagai kendaraan politik. Terbukti mulai dari pemilu 1971 sampai dengan pemilu 1997, Partai Golkar selalu menduduki ranking 
pertama dalam perolehan suara dibanding partai politik lainnya. Dengan kata lain Partai Golkar selalu menjadi pemenang dalam setiap peristiwa pemilu, meskipun kemenangannya sering diikuti dengan kontroversi penghitungan suara.

Untuk memperoleh dukungan massa melalui Partai Golkar, pihak penguasa (baca: pemerintah rezim Orde Baru) memandang perlu untuk menggunakan instrumen kesenian sebagai media untuk menarik massa. Salah satu kesenian yang digunakan untuk memperoleh simpati masyarakat adalah seni pedalangan. Dalang sebagai orang pintar (intelektual sekaligus aktor) di daerah dipandang amat potensial untuk menyampaikan pesan dan ajakan kepada masyarakat. Oleh karenannya, para dalang ditunjuk pihak penguasa sebagai juru kampanye untuk menggalang massa Partai Golkar.

Para dalang yang berhasil menjadi jurkam, dan memenangkan Partai Golkar di daerah tujuan kampanye, diberi hadiah oleh penguasa, di antaranya mobil mewah dan diberi kesempatan untuk melakukan ibadah haji. Dengan insentif ini, penguasa dapat mendikte, mengontrol, dan membina dalang dan sen pewayangan, sesuai dengan kebijakan yang dicanangkan beserta tujuan praktek kenegaraan (Hadiz, 1998). Dalam suatu pertunjukan, wayang melukiskan gambaran yang bukan saja kehidupan dan negara yang diidealkan, akan tetapi juga kebijakan serta praktek-praktek kekuasaan (Moertono, 1963).

Hampir setiap pertunjukan wayang kulit, seorang dalang melontarkan program-program pembangunan sebagai bentuk pendektean kekuasaan, antara lain tentang panca usaha tani, intensifikasi pertanian, penghijauan, modernisasi desa, eka prasetya panca karsa (P4), siskampling, kadarkum, dan lain-lainnya. Bahkan dalam rangka mengkampanyekan Partai Golkar, negara mengintervensi pertunjukan wayang kulit, yang diwujudkan dalam bentuk cerita bertema pohon beringin dan dominasi warna kuning, seperti: Pandawa Ringin, Ringin Kembar, Waringin Kencana, Semar Kuning,, dan Semar Mbangun Gedung Kencana. Usaha untuk memasyarakatkan Golkar melalui campur tangan negara terhadap kesenian ini tidak hanya dalam hal lakon/cerita saja, akan tetapi penguasa juga membentuk dua organisasi seni pedalangan/pewayangan. Pertama, Senawangi (Sekretariat Nasional Pewayangan Indonesia), merupakan organisasi yang mengurusi masalah wayang $\mathrm{d}$ seluruh Indonesia. Kedua, Pepadi (Parsatuan Para Dalang Indonesia), merupakan organisasi yang mengurusi dalang di seluruh Indonesia. Nama sebelum Pepadi adalah Ganasidi (Lembaga Pembina Seni Pedalangan Indonesia).

Tercatat dalam sejarah pemerintahan Orde Baru, bahwa sekitar lima tahun menjelang akhir kekuasaannya, para dalang diminta untuk mementaskan lakon Semar mBabar Wahyu Jati Diri, sebuah lakon yang bertema persoalan suksesi (lengser keprabon). Sebuah lakon yang dalam banyak tafsiran masyarakat, menunggu Presiden Soeharto akan segera turun dari istana dan diganti oleh orang kepercayaan yang telah disiapkan sebelumnya, menjadi pegangan para dalang untuk mementaskan lakon tersebut. Campur tangan dalam bentuk urusan wayang dan dalang ini merupakan bentuk hegemoni kekuasaan terhadap kesenian, khususnya seni pewayangan. Bentuk hegemoni ini dikaji dalam tulisan ini.

Nancy Ann Guy (1997) dalam laporannya tentang "Peking Opera and Politics in Post-1949 Taiwan" mengungkapkan kesenian yang dikontrol oleh negara, seperti terjadi pada seni pertunjukan "Peking Opera" di Taiwan dapat merefleksi kebijakan serta ideologi yang dibangun oleh sebuah rezim untuk menentukan langkah-langkah pemerintahannya. Penelitian Guy ini bermaksud untuk menguji tujuan, mekanisme, dan konsekwensi negara dalam mengontrol kehidupan kesenian (Guy, 1997)

Penelitian tentang hegemoni budaya diungkapkan juga dapat dijumpai dalam laporan studi berjudul "Imaging Culture: Art and Nationalism in Ghana" (Hess, 2000). Dalam laporan studi ini disebutkan bahwa kesenian dijadikan sebagai alat untuk membangun sebuah kebudayan nasional. Di samping itu, kesenian mampu menjamin asosiasi antara otoritas negara, kesenian itu sendiri, dan bahkan menjadi konstitusi. Hal tersebut mengindikasikan bahwa kesenian menjadi perwujudan perjuangan nasionalisme.

Tulisan Mayo (2002) berjudul "Cultures, Communities, Identities: Cultural Strategies for Participation and Empowerment". "Cultures, Communities, Identities: Cultural Strategies for Participation and Empowerment", di dalamnya disebutkan adanya kebijakan sosial dan intervensi negara terhadap kebudayaan. Laporan ini lebih menitikberatkan pada peran negara dalam membina kebudayaan rakyat, baik secara komunikatif maupun membentuk identitas kebudayaan.

Demikian pula hasil studi berjudul "Love for Labour Lost: How does thing Theatre Director feel after ten months of arts policy? Like the Turkey who voted for Christmas" (Bogdanov, 1998) disebutkan bahwa orkestra mengalami merger, teater ditutup, dan dalam wacana kesenian tidak terlihat adanya tanda-tanda kehidupan kesenian. Satu-satunya langkah agar kesenian itu dapat hidup bergairah lagi adalah harus mau dihegemoni oleh pihak lain, di antaranya adalah negara.

Negara mempunyai peranan untuk memelihara nilai-nilai kebudayaan (Chang, 2003) seperti terjadi di Singapura. Demikian juga pernah dipertanyakan siapa penjaga kebudayaan itu? Jawabannya adalah negaralah yang bertanggung jawab. Selama abad ke-20 negara memainkan peranan besar dalam mendukung lembaga kebudayaan, seperti halnya museum serta gedung-gedung pertunjukan (Kennedy, 2002).

Berdasarkan hal tersebut dapat diasumsikan bahwa campur tangan kekuasaan terhadap kesenian merupakan bentuk hegemoni budaya, yang di dalamnya terkandung tujuan untuk melanggengkan kekuasaan pemerintahan. Namun yang perlu mendapat perhatian sebagai pokok persoalan dalam tulisan ini 
adalah seputar kekuasaan dalam menghegemoni dalang dan seni pewayangan? Bertitik tolak dari persoalan tersebut dirumuskan pertanyaannya sebagai berikut: (1) Mengapa kekuasaan melakukan campurtangan (hegemoni) terhadap sen pedalangan? (2) Mengapa para dalang dipilih menjadi juru kampanye Partai Golkar. Bukankah penguasa mempunyai tangan-tangan atau staf-staf ahli politik Apa kelebihan dalang? dan (3) Mengapa pertunjukan wayang dijadikan sebagai instrumen kampanye Partai Golkar. Apa kelebihan pertunjukan wayang? Jawaban ketiga pertanyaan ini di antaranya diramu dengan teori hegemoni yang ditawarkan oleh Antonio Gramsci sebagai berikut.

\section{WAYANG DAN SENI PEDALANGAN DI INDONESIA}

\section{Kekuasaan dan Hegemoni}

Tulisan ini akan memahami satu pokok bahasan yaitu antara kekuasaan dan kesenian. Permahaman ini menyangkut bentuk afiliasi antara dalang wayang kulit (seniman) dengan pihak penguasa dalam hal ini adalah pemerintah atau negara (state). Aspek sub-bidang kajian ini adalah pertunjukan wayang kulit Jawa yang cukup mengental dengan kehidupan budaya masyarakat Jawa.

Rezim Orde Baru dipandang sebagai pihak penguasa atas nama negara kuat yang selalu dapat menentukan arah pertunjukan wayang kulit. Sebagai keikutsertaannya untuk mencampuri pertunjukan wayang kulit bertujuan membangun basis kekuasaan negara melalui seni tradisional. Hasil campur tangan penguasa ini terlihat para dalang menerima dan menyadari hegemoni penguasa (rezim Orde Baru) yang dipandang sebagai bentuk pendektean itu. Sebagai catatan, rezim Orde Baru adalah negara-pemerintah otoriter-birokratik, yang didukung oleh kekuatan militer (Masso, 2002). Negara yang kuat akan mudah untuk menentukan langkah-langkah hegemoni.

Hegemoni dalam bahasa Yunani kuno disebut eugemonia, seperti telah dipaparkan dalam Encyclpedia Britanica yang menceritakan prakteknya di Yunani, diterapkan untuk menunjukkan dominasi posisi yang diklaim oleh negara-negara kota (polis atau citystates) secara individual, seperti yang dilakukan oleh negara kota Athena dan Sparta terhadap negara-negara lain yang sejajar (Hendarto, 1993).

Pengertian hegemoni di di era sekarang menunjukkan sebuah kepemimpinan dari suatu negara tertentu, yang bukan saja sebagai negara kota yang melakukan hegemoni terhadap negara-negara lain yang berhubungan secara longgar maupun secara ketat terintegrasi dalam negara pemimpin (Sperling, 2001) Dalam konsep hegemoni yang dikemukakan Gramci sebenarnya dapat dielaborasi melalui penjelasannya tentang sebuah basis dari supremasi kelas, yakni bahwa supremasi sebuah kelompok sosial mewujudkan diri dalam dua cara, sebagai dominasi dan sebagai kepemimpinan intelektual dan moral (Patria, 2003).
Di satu sisi, sebuah kelompok sosial mendominasi (menguasai) kelompokkelompok oposisi untuk menghancurkan mereka, bahkan kalau perlu mempergunakan kekuatan senjata. Di sisi lain, sebuah kelompok sosial itu memimpin kelompok-kelompok kerabat dan sekutu mereka. Sebuah kelompok sosial dapat dan bahkan harus sudah menerapkan kepemimpinan sebelum memenangkan kekuasaan pemerintahan. Kelompok sosial tersebut kemudian menjadi dominan ketika dia mempraktekkan kekuasaan. Bahkan setelah kelompok sosial itu memegang kekuasaan penuh di tangannya, ia masih harus terus memimpin dan melakukan langkah-langkah untuk melanggengkan kekuasaannya.

Gramci juga menyebutkan bahwa hegemoni adalah sebuah rantai kemenangan yang didapat melalui mekanisme konsensus ketimbang melalui penindasan terhadap kelas sosial lainnya. Terdapat berbagai cara yang digunakan, misalnya melalui institusi yang ada di masyarakat yang menentukan secara langsung atau tidak langsung struktur-struktur kognitif dari masyarakat. Dari penjelasan ini dapat diketahui bahwa hegemoni pada dasarnya adalah upaya untuk menggiring orang agar menilai dan memandang problematika sosial dalam kerangka yang ditentukan.

Dalam konteks ini, Antonio Gramci merumuskan konsepnya yang merujuk pada pengertian tentang situasi sosial-politik, dalam terminologinya yang mana filsafat dan praktek sosial masyarakat menyatu dalam keadaan seimbang. Kemudian dominasi itu sendiri merupakan konsep dari realitas yang menyebar melalui masyarakat dalam sebuah lembaga dan manifestasi perseorangan. Pengaruh in membentuk moralitas, adat, religi, prinsip-prinsip politik dan semua realitas sosial. Dengan demikian bahwa hegemoni selalu berhubungan dengan penyusunan kekuatan negara sebagai kelas ditaktor. Di samping itu, hegemoni juga merujuk pada kedudukan ideologis satu atau lebih kelompok atau kelas dalam masyarakat sipil yang lebih tinggi dari yang lain (Bellamy, 1987).

Gramsci juga melihat kenyataan bahwa di dalam masyarakat selalu terdapat kelompok yang memerintah dan yang diperintah. Persoalan bagi yang memerintah adalah bagaimana menciptakan kepatuhan dan meniadakan perlawanan dari yang diperintah. Jalan yang ditempuh Gramsci untuk mewujudkan hal itu adalah penguasa mempergunakan cara lewat dominasi atau penindasan dalam bentuk kekuatan (force) dan hegemoni yakni memegang kendali kepempimpinan intelektual dan moral yang diterima secara sukarela lewat kesadaran (Billah, 1996).

Dengan penjelasan tentang hegemoni ini terlihat bahwa rezim Orde Baru merupakan pemerintah/negara kuat yang memiliki otoritas tertinggi, serta menjadi kekuatan penentu terhadap dinamika sosial-politik masyarakat. Penguasa benarbenar mampu memimpin dan mendominasi lapangan kekuasaan dalam berbagai 
bidang pembangunan dan kenegaraan. Sebagai negara dengan posisi kuat, memimpin, dan mendominasi akan mudah untuk menentukan langkah-langkah hegemoni, guna melestarikan/memperpanjang kekuasaan. Salah satu cara potensial yang digunakan penguasa untuk menghegemoni, di antaranya melalui institusi yang memiliki dan menentukan struktur kognitif di masyarakat, dalam hal ini adalah seni pedalangan mengingat jenis pertunjukan ini mengakar dalam masyarakat Jawa. Dengan konsekwensi, para dalang sebagai kekuatan intelektual di masyarakat, dikendalikan penguasa untuk menyampaikan konsep, Ideologi, dan kekuasaan yang telah ditata.

\section{Dalang sebagai Intelektual Tradisional}

Gramci mencoba menganalisis cara suatu aturan politik dan hegemon sebuah kelas dalam sebuah blok sejarah secara nyata diaktualisasikan, dan secara konkrit telah terorganisir, yaitu menguji persoalan peran intelektual sebagai bagian dari tujuannya untuk memahami kesatuan nyata dari basis superstruktur. Dalam hal ini, Gramci membagi skematisasi peran intelektual menjadi dua pilah, yaitu: (1) intelektual organik, dan (2) intelektual tradisional (Patria, 2003).

Intelektual organik adalah intelektual yang langsung berhubungan dengan cara produksi yang dominan. Setiap kelas sosial yang muncul dari basis produks ekonomi, menciptakan sendiri kelompok-kelompok intelektual yang memberikan homogenitas serta kesadaran terhadap fungsinya, bukan saja dalam lapangan ekonomi, akan tetapi juga dalam lapangan sosial dan politik. Sebagaimana para pengusaha kapitalis menciptakan sendiri teknisi industrial, ekonom politik, para agen pembentuk kebudayaan baru, dan pembentuk hukum baru.

Intelektual tradisional adalah intelektual yang bertugas untuk memimpin secara intelektual dalam suatu masyarakat. Berbagai kategaori intelektual tradisional mempunyai citra terhadap kesinambungan sejarah yang tidak putus terhadap kualifikasi-kualifikasi sebuah esprit de corps, yang artinya mereka memandang dirinya sebagai kelompok sosial yang berkuasa (otonom) dan independen.

Kaum intelektual tradisional dalam masyarakat dipresentasikan melalui manusia literer (literary man), para filsof, dan para seniman. Dalam hal ini para dalang wayang kulit termasuk kaum intelektual tradisional. Sebagai seniman, dalang adalah manusia literer yang sekaligus filsuf. Sebagai intelktua tradisional, para dalang wayang kulit juga termasuk bagian dari kelompok sosial yang berkuasa, karena mereka memiliki (menguasai) massa penggemar.

Para dalang bersama-sama dengan penguasa (lewat partai Golkar) dipandang sebagai bentuk afiliasi, sebagaimana juga pernah tercatat dalam sejarah demokrasi liberal jaman Bung Karno, terdapat organisasi-organisasi kesenian yang berafiliasi dengan kekuatan-kekuatan politik tertentu, seperti Lekra-PKI
(Lembaga Kebudayaan Rakyat-Partai Komunis Indonesia), Lesbumi-NU (Lembaga Seni Budaya Muslim Indonesia-Nahdlatul Ulama), dan LKN-PNI (Lembaga Kebudayaan Nasional-Partai Nasional Idonesia), dan sebagainya. Bentuk afiliasi ini membuahkan para dalang wayang kulit itu terhegemoni oleh kekuasaan-rezim Orde Baru. Posisi dalang wayang kulit tetap dijadikan sebagai pedoman dari konsep intelektual (intelektual tradisional) yang merupakan dari bagian masyarakat sipil dan negara.

Jenis intelektual tradisional merupakan intelektual yang dapat dikategorikan sebagai intelektual otonom, dan ketegori ini muncul sebagai wakil dari suatu kontinuitas historis yang tidak terputus oleh perubahan-perubahan yang radikal dan rumit dalam bentuk sosial dan politik. Bila dilihat bentuk pertunjukan wayang kulit dari dulu hingga sekarang, atau yang telah dilakukan dalang setiap pentasnya merupakan kesinambungan yang tetap sama, meskipun negara mengalami perubahan sosial dan politik. Perubahan dalam diri dalang sebagai intelektual tradisional akan terlihat, ketika ia memperoleh sebuah pendiktean dari pihak penguasa. Sebagai intelektual tradisional, dalang dibina penguasa untuk menyampaikan pesan dalam suatu kampanye (Jackeman, 1999). Seorang dalang dapat menjadikan wayang sebagai refleksi terbaik bagi kehidupan orang Jawa, dan juga menceritakan hubungan antara raja dan rakyatnya secara ideal (Moertono, 1964). Dengan kata lain cerita wayang dapat dijadikan sebagai refleksi kehidupan untuk memupuk hubungan negara dan rakyat. Selain itu, seorang dalang juga sekaligus memberikan hiburan untuk masyarakat luas, mengingat massa di Jawa sangat kental dengan seni tradisional, artinya ketika di suatu tempat terdapat pertunjukan maka di tempat itu juga berkumpul massa. Dengan demikian para dalang yang telah dihegemoni oleh negara menjadi instrumen yang ampuh untuk menyampaikan pesan negara kepada rakyat.

Pertunjukan Wayang sebagai Ekspresi Sosial

Menurut Gramci, partai harus terdiri dari tiga elemen, yaitu: (1) basis rakyat yang populer, (2) kepemimpinan, dan (3) elemen penengah (Patria, 2003). Di dalam tubuh partai Golkar mencerminkan sebersit tiga hal pokok tersebut, karena partai ini dibangun melalui basis kerakyatan, didukung para aktor-aktor intelektual yang memadai (para pemimpin dan calon-calon pemimpin), dan ia menjadi mediator dari berbagai konflik politik, sosial, budaya yang telah lama di Indonesia. Berdasarkan hal tersebut Partai Golkar seharusnya mempunyai basis kerakyatan yang semakin lama semakin berkembang, bukan semakin berkurang. Oleh karenanya untuk memperluas jumlah pendukung massa Partai Golkar diperlukan media kesenian yang telah mengental di masyarakat yaitu pertunjukan wayang. Hal tersebut dikarenakan pertunjukan wayang sangat dekat dengan masyarakat, terlebih masyarakat bawah yang jumlahnya amat besar untuk diraup 
sebagai massa Partai Golkar. Oleh karenanya sangatlah tepat, jika pertunjukan wayang digunakan sebagai instrumen kampanye dalam memperluas massa partai Golkar.

Dalam sejarah perkembangannya, pertunjukan wayang sudah lama dipergunakan untuk membangun komunikasi politik (Stamatov, 2002). Sejak berfungsi sebagai pembangkit semangat perjuangan pada masa kolonial, dan sebagai media kampanye partai politik era Orde Lama hingga Orde Baru, pertunjukan wayang terlihat peranan dan fungsinya sebagai media ekspresi sosial karena di dalam pertunjukannya dapat dibangun gerakan sosial-politik untuk ditujukan kepada masyarakat. Hal ini disebabkan pertunjukan wayang sebagai teater terdapat spectacle social (demo/pertunjukan sosial) untuk bereaksi di hadapan penonton. Sebagai ekspresi sosial, tentu pertunjukan wayang amat potensial untuk membangkitkan semangat bagi masyarakat luas. Oleh karenanya, kesenian ini akan menjadi instrumen hegemoni negara yang memadai. Seperti halnya telah dibicarakan di atas, seni pedalangan di samping sebagai alat hegemoni, juga mampu dipergunakan sebagai alat resistensi terhadap negara.

Ketika proses sosialisasi berjalan, ekspresi sosial pertunjukan wayang menanamkan sikap dan orientasi kehidupan politik yang berlangsung dalam masyarakat. Demikian juga masyarakat (penonton) akan menentukan sikap terhadap janji-janji dan kebijakan yang telah digariskan oleh penguasa melalui media pertunjukan wayang, sehingga apa yang telah diperjuangkan penguasa dapat memenuhi berbagai kepentingan atau menampung kepentingan masyarakat secara luas.

Sebagai ekspresi sosial yang mampu digarap menjadi instrumen hegemoni, pertunjukan wayang merupakan wahana yang sangat ampuh dalam menyebarkan nilai-nilai pembangunan atau ide-ide partai politik/penguasa. Peran dan fungsinya sangat dibutuhkan karena pertunjukan wayang merupakan aktualisasi konsep kehidupan yang mengajarkan mentalitas dan moralitas. Melalui pertunjukannya, ia dapat merubah diri manusia yang menghayatinya, yaitu berupa pengembangan sikap mental yang diperlukan dalam membangun negara.

Selain itu, sebagai ekspresi social pertunjukan wayang tidak melulu untuk kampanye partai politik, akan tetapi lebih jauh pergelarannya tetap belanjut untuk mendukung program-program pembangunan yang dijalankan dan disesuaikan dengan misi penguasa (rezim Orde Baru). Hal ini tampak dari berbagai repertoar cerita wayang yang ditampilkan selama kejayaan penguasa di masa pemerintahan rezim Orde Baru, yang tidak saja berbau lakon-lakon kampanye seperti Pandawa Ringin, Ringin Kembar, Waringin Kencana, dan Semar Mbangun Gedung Kencana, akan tetapi juga bagaimana pertunjukan wayang menampilkan lakonlakon lain namun di dalamnya terdapat pesan-pesan pembangunan lewat adegan gara-gara. Dalam adegan ini sering disuguhkan dialog yang mengulas tentang program-program pembangunan antara lain penghijauan, kebersihan, panca usaha tani, kadarkum, kamtibmas, siskampling, PKK, P4, modernisasi desa, lumbung desa, ibu pertiwi, lalu-lintas, dan sebagainya. Padahal jika dicermati program-program yang telah disebutkan itu di dalamnya tersirat adanya legitimasi kekuasaan negara, meskipun masyarakat kadang-kadang kurang memahami. Bahkan sebaliknya masyarakat dibangun untuk merasa senang dan patuh terahadap program-program tadi, yang ujung-ujungnya adalah patuh terhadap penguasa atau dengan kata lain rakyat mengalami ketertundukan oleh negara. Dalam artian penguasa memperoleh dukungan massa, atau paling tidak dapat mempertahankan jumlah dukungan massa, yang berarti pula negara dapat memperlama kekuasaannya.

\section{SIMPULAN}

Kajian hegemoni kekuasaan terhadap seni pedalangan akan terarah jika harus melihat secara lurus pada tawaran Gramsci yang menyebutkan bahwa hegemoni memberikan definisi terhadap konsep politik dan konsekwensi pada tugas yang harus diemban oleh partai politik (Gramsci, 1976). Dalam hal ini partai politik harus mampu mengelola instrumen hegemoni untuk mengelabuhi masyarakat luas agar menjadi patuh dan mau dikuasai oleh partai politik tersebut. Seperti langkah-langkah yang diambil oleh partai Golkar sebagai kendaraan politik rezim penguasa Orde Baru ini adalah mengelola pertunjukan wayang sebagai wadah ekspresi sosial dan interaksi antara penguasa dan rakyat. Sebelum wadah ini efektif dan memadai, maka instrumen itu (seni pedalangan) harus dihegemoni terlebih dahulu, dalam artian bentuk kesenian tersebut beserta dalang dan komunitasnya harus ditakhlukkan, agar semua pesan dan pendektean penguasa terhadap kesenian ini, benar-benar dapat menjadi kuda emas (kendaraan politik yang manis dan jitu).

Tentu saja seni pedalangan harus dapat dikelola secermat mungkin, karena sosialisasi dan ekspresi kesenian ini tidak hanya sebatas ketika kampanye dijalankan, akan tetapi juga ketika aktivitas kampanye selesai dan partai penguasa telah menjadi pemenang dalam pemilihan umum. Melihat dari kenyataan ini, kiranya sangat tepatlah, sebagai alat hegemoni seni pedalangan itu diproduksi karena memuat suatu sifat dan makna pada konteks sosio-kultural masyarakatnya (Camus, 1998). Dengan menghegemoni seni pedalangann, penguasa (pemerintah/Negara) juga mendapat legitimasi kekuasaan dari masyarakat (Budiman, 1997). Pernyataan ini mengisyaratkan bahwa dengan ekspresi kesenian sebagai alat hegemoni, penguasa mengharapkan dukungan, simpati, dan ketaatan masyarakat luas untuk tunduk dan patuh terhadap kekuasaan yang dipegang oleh pemerintah. Praktek hegemoni budaya yang diterapkan penguasa seperti ini juga telah terbukti dalam lintasan sejarah kerajaan di nusantara, sebagaimana pernah 
dilakukan oleh Ken Arok (lewat karya Pararaton), Jayabaya (lewat karya Bharatayuda), Hayam Wuruk (lewat karya Bhineka Tunggal Ika), Sultan Agung (lewat karya sastragendhing), dan yang kemudian dipraktekkan lewat seni pertunjukan adalah Paku Buwono I (lewat tari bedhaya Ketawang), Paku Buwono $\mathrm{X}$ (lewat wayang gedhog), Hamengku Buwono I (lewat tari Lawung Ageng), dan Hamengku Buwono VII (lewat wayang wong gagrak Ngayogyakarta).

Praktek hegemoni budaya yang telah disebutkan itu dapat dipandang sebagai aplikasi praktek hegemoni dari sebuah pemikiran yang dilontarkan kaum Marxis (sebagaimana juga dianut Gramsci). Pemikiran kaum Marxis menyatakan bahwa kebudayaan yang ada dalam suatu masa merupakan kebudayaan milik kelas yang sedang berkuasa. Mengacu pada pemikiran kaum Marxis, seni pedalangan menjadi kesenian milik kelas yang sedang berkuasa waktu itu, yaitu rezim Orde Baru. Sebagai bukti hampir seluruh dalang masuk dalam organisasi Pepadi atau Ganasidi, seperti telah dibicarakan di depan. Setahu penulis, hanya seorang dalang berasal dari Klaten, yang hingga pemerintah Orde Baru runtuh tidak bersedia menjadi anggota organisasi tersebut. Ia memilih masuk PDI, dengan alasan bahwa orang tuanya yang juga seorang dalang dibantai pada masa pergolakan sosial pasca G/30/S-PKI di Klaten 1965, karena dianggap ikut dalam organisasi terlarang.

Dengan demikian, ekspresi seni pedalangan yang terjadi adalah ekspresi kesenian yang dibangun oleh kelas penguasa. Dengan ini pula dapat disimpulkan bahwa pemerintah dan rezim Orde Baru dapat dipandang sebagai bentuk penguasa yang telah sukses menghegemoni seni pedalangan. Para dalang mau menerima hegemoni budaya yang diterapkan oleh penguasa. Dampak hegemon budaya adalah para dalang tidak melakukan resistensi atau gerakan perlawanan terhadap kekuasaan.

\section{DAFTAR PUSTAKA}

Bellamy, Richard. 1987. Modern Italian Social Theory, From Pareto to the Present. Terjemahan Vedi R. Hadiz, Teori Sosial Modern: Perspektif Italia. Jakarta: LP3ES.

Billah, M.M.. 1996. "Good Gorvenance dan Kontrol Sosial Realitas dan Prospek". Prisma, 8 Agustus, p. 43

Bogdanov, Michael. 1998. "Love for labour Lost: How does thing Theatre Director feel after ten months of arts policy? Like the Turkey who voted for Christmas". New Statesman, 27 February, pp. 40-41.

Budiman, Arief. 1997. Teori Negara, Kekuasaan, dan Ideologi. Jakarta: Gramedia.

Chang, Johanes Han-Yin. 2003. "Culture, State, and Economic Development in Singapore". Journal of Contemporary Asia, Vol 33, Num. 1, pp. 85-102. Camus, Albert. 1998. Seni, Politik, dan Pemberontakan. Yogyakarta, Yayasan
Bentang Budaya, p. xxix.

Geldern, Robert Hein. 1982. The God King. Terjemahan: Kekuasaan Raja Dewa. Jakarta: Gramedia Pustaka Utama.

Gramsci, Antonio. 1976. Selections From The Prisson Notebooks, Quintin Hoare and Nowell Smith (ed.). New York: International Publisher.

Guy, Nancy Ann. 1997. "Peking Opera and Politics in Post-1949 Taiwan". $\mathrm{Ph}$.D. dissertation, University of Pittsburgh, USA.

Hadiz, Verdi R. 1998. "Workers and the State in New Order Indonesia" Pacific Affairs, fall, pp. 447-449.

Hendarto, Heru. 1993. "Mengenai Konsep Hegemoni Gramsci", dalam Diskursus Kemasyarakatan dan Kemanusiaan. Tim Redaksi Driyarkara. Jakarta: Gramedia.

Hess, Janet Beny. 2000. "Imaging Culture: Art and Nationalism in Ghana". Dissertation, Harvard University, USA

Jackerman, Jane. 1999. "Propaganda Value art". New Statesman, Aug 16, pp. 34-35 Kennedy, Richard S. 2002. "Who is Culture's Keeper?" Journal of Foreign Policy, Nov, pp. 92-94.

Kristiadi, Joseph. 1994. "Pemilihan Umum dan Perilaku Pemilih : Suatu Studi Kasus tentang Perilaku Pemilih di Kodya Yogyakarta dan Kabupaten Banjarnegara (Jawa Tengah) pada Pemilu 1971-1987”. Desertasi S-3, Program Pascasarjana Universitas Gadjah Mada, Yogyakarta.

Masso, Ivan. 2002. "Why I Hate Our Official Art?" New statesman, January, pp. $11-12$.

Mayo, Marjorie. 2002. "Cultural, Communities, Identities: Cultural Strategies for Participation and Empowerment" Journal of Social Polity, January, pp. 172-173.

Moedjanto, G. 1994. Konsep Kekuasaan Jawa: Penerapannya oleh Raja-raja Mataram. Yogyakarta: Kanisius.

Moertono, Soemarsaid. 1963. State and Statecraft in Old Java: A Study of the Later Mataram Period, 16 to 19 Century. Ithaca, New York: Modern

Indonesia Project, Southeast asia Program, Cornell University.

Moffat, Alistair. 2000. "We Can’t Afford An Opera Company". New Statesman, March, p. 35.

Patria, Nezar dan Andi Arief. 2003. Antonio Gramsci Negara dan Hegemoni. Yogyakarta: Pustaka Pelajar.

Sperling, James. 2001. "Neither Hegemony Nor Dominance: Reconsidering German Power in Post Cold-war Europe". British journal of Political Science, March, pp. 389-425. 